F. Reprod. Fert. (1970) 23, 327-329

\title{
STIMULATION OF RNA SYNTHESIS IN THE BLASTOCYST AND UTERUS OF THE RAT BY ADENOSINE 3'5'-MONOPHOSPHATE (CYCLIC ApMP)
}

\author{
SURESH MOHLA AND M. R. N. PRASAD \\ Department of Zoology, University of Delhi, Delhi-7, India
}

(Received 7th April 1970, revised 22nd June 1970)

In earlier studies which showed that oestrogen activates the synthesis of RNA, DNA and protein in the blastocyst and uterus during delayed implantation, it was postulated that activation of the delayed blastocyst might be due to the direct action of oestrogen (Mohla, 1968; Prasad, Dass \& Mohla, 1968; Dass, Mohla \& Prasad, 1969).

One of the earliest effects of oestrogen on the rat uterus is the release of adenosine $3^{\prime} 5^{\prime}$-monophosphate (cyclic ApMP), the levels of which are enhanced within $15 \mathrm{sec}$ after the intravenous administration of oestrogen (Szego \& Davis, 1967). Griffin \& Szego (1968) showed that cyclic ApMP, like oestrogen, enhanced within 5 min the incorporation of labelled amino acids into the protein of uterine segments of untreated ovariectomized rats. They postulated that the cyclic ApMP released as a result of oestrogen treatment also participates in the early effects of oestrogen on the uterus. A further effect, noted within $5 \mathrm{~min}$ of treatment with oestrogen, is an increase in the incorporation of $\left[{ }^{3} \mathrm{H}\right]$ uridine into RNA in the blastocyst and uterus (Mohla \& Prasad, 1970). It was, therefore, of interest to study the effect of cyclic ApMP on the incorporation of $\left[{ }^{3} \mathrm{H}\right]$ uridine into RNA in the blastocyst and uterus of the rat during delayed implantation.

Colony-bred, adult, virgin, female, albino rats of the Holtzman strain (240 to $280 \mathrm{~g}$ ) were maintained in light-controlled ( $14 \mathrm{hr}$ light $/ 10 \mathrm{hr}$ dark), airconditioned rooms $\left(25 \pm 1^{\circ} \mathrm{C}\right)$ and fed a standard diet. Delayed implantation was induced by the method of Cochrane \& Meyer (1957), i.e. mated females were bilaterally ovariectomized on Day 3 of pregnancy (the first day of finding spermatozoa in the vagina was designated Day 1 of pregnancy) and were given $4 \mathrm{mg} /$ day of progesterone in olive oil till the termination of the experiment. Precursors were instilled into the uterine lumen according to methods described in our earlier studies (Prasad et al., 1968; Dass et al., 1969). The following experiments were performed on Day 9 of delayed implantation. $\mathrm{N}^{6}$-2-0 dibutyryl adenosine $3^{\prime} 5^{\prime}$ monophosphate (cyclic ApMP, Cal. Biochem., Lot No. 920036) was dissolved in sterile physiological saline ( $\mathrm{pH} \mathrm{7.40).} \mathrm{The}$ experimental group (eight rats) received an intraluminal injection of $0.05 \mathrm{ml}$ saline ( $\mathrm{pH} \mathrm{7.40)}$ containing $1.25 \mathrm{~mm}$ cyclic ApMP and $1 \mu \mathrm{c}$ of $\left[{ }^{3} \mathrm{H}\right]$ uridine (Sp.Act. 6.0 Gi/mm; Schwartz Bioresearch)/uterine horn. The control animals (ten rats) received an intraluminal injection of $1 \mu \mathrm{c}$ of $\left[{ }^{3} \mathrm{H}\right]$ uridine in $0.05 \mathrm{ml}$ 
of physiological saline $(\mathrm{pH} \mathrm{7 \cdot 40)/uterine} \mathrm{horn} \mathrm{for} \mathrm{the} \mathrm{same} \mathrm{time} \mathrm{period.} \mathrm{The}$ animals were killed 15 min after the injections.

At the time of autopsy, the uterine horns were flushed with physiological saline and the blastocysts were collected. The blastocysts and uteri were processed for autoradiography as described by Prasad et al. (1968). The slides were coated with diluted $(1: 2)$ Kodak nuclear track emulsion NTB3 and the autoradiographs were developed after 7 and 21 days of exposure for the blastocysts and uteri, respectively. The autoradiographs were developed in Kodak D-19 developer for $5 \mathrm{~min}$ at $18^{\circ} \mathrm{C}$ and acid-fixed. The slides were stained through the emulsion with buffered methyl-green pyronine or with haematoxylin and eosin. The extent of labelling in the uterine epithelium was assessed by scanning 500 cells selected at random and the results were expressed as a percentage of the number of uterine epithelial cells examined. The number of grains/cell was counted in 100 blastocyst or uterine epithelial cells. Any cell showing three or four grains above the background count was scored as labelled.

TABLE 1

INCORPORATION OF $\left[{ }^{3} \mathrm{H}\right]$ URIDINE BY THE BLASTOCYST AND UTERUS

\begin{tabular}{|c|c|c|c|}
\hline Group & $\begin{array}{l}\text { Blastocyst } \\
\text { grains/cell }\end{array}$ & $\begin{array}{l}\text { Uterine } \\
\% \text { cells } \\
\text { labelled }\end{array}$ & $\begin{array}{l}\text { bithelium } \\
\text { grains/cell }\end{array}$ \\
\hline $\begin{array}{l}\text { Control } \\
\text { (delayed implantation) }\end{array}$ & 4 & 29 & 3 \\
\hline $\begin{array}{l}\text { Experimental } \\
\text { (cyclic ApMP } 15 \text { min) }\end{array}$ & 24 & 91 & 14 \\
\hline
\end{tabular}

The incorporation pattern of $\left[{ }^{3} \mathrm{H}\right]$ uridine by the blastocyst and uterus in the two groups is shown in Table 1 and Plate 1. During delayed implantation, a minimal amount of RNA synthesis was evident in the blastocyst (Pl. 1, Fig. 1) and uterus (Pl. 1, Fig. 2). In the delayed blastocyst (twenty-eight blastocysts), the incorporation into nuclear RNA was seen in all regions of the blastocyst (average of four grains/cell). The cyclic ApMP enhanced the incorporation of $\left[{ }^{3} \mathrm{H}\right]$ uridine in all regions of the blastocyst (seventeen blastocysts) within 15 min of injection (Pl. 1, Figs. 3 and 5). The incorporation was specifically in the nucleus; there was, however, a six-fold increase in the number of grains/cell over that of the delayed implantation controls (Table 1). In the uterus, cyclic

\section{EXPLANATION OF PLATE 1}

Fig. 1. A few of the cells of the delayed blastocyst after a 15 -min exposure to $\left[{ }^{3} \mathrm{H}\right]$ uridine. A few grains are seen over the nuclei. Methyl-green pyronine. $\times 950$.

Frgs. 2 and 5. A few of the cells of the blastocyst after a 15-min exposure to cyclic ApMP and $\left[{ }^{3} \mathrm{H}\right]$ uridine. Heavy incorporation is seen in all regions of the blastocyst (Fig. 5), but specifically in the nuclei (Fig. 2). Methyl-green pyronine. Fig. $2 \times 950$, Fig. $5 \times 400$.

Fig. 3. Part of the uterine epithelium of a delayed rat $15 \mathrm{~min}$ after exposure to $\left[{ }^{3} \mathrm{H}\right]$ uridine. Some of the uterine epithelial nuclei are labelled. Haematoxylin-eosin $\times 1500$.

Fig. 4. Part of the uterine epithelium of an experimental rat $15 \mathrm{~min}$ after exposure to cyclic ApMP and $\left[{ }^{3} \mathrm{H}\right]$ uridine. The uterine epithelial nuclei are heavily labelled. Haematoxylin-eosin. $\times 1300$. 


\section{PLATE 1}
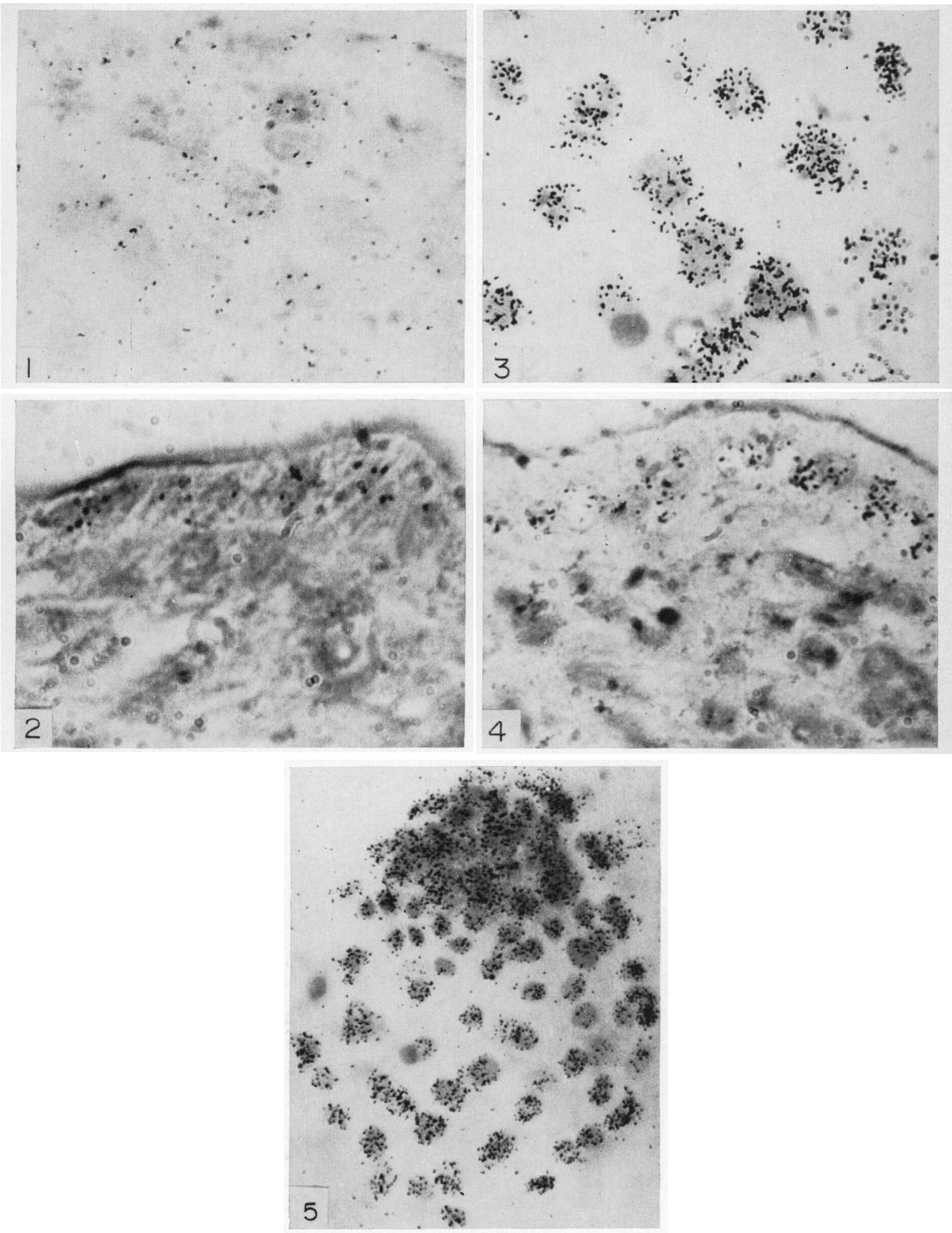

(Facing p. 328) 
ApMP caused a three-fold increase in the percentage of labelled uterine epithelial cells and a four-fold increase in the number of grains/cell; the grains were located in the nuclei of uterine epithelial cells (Table I and Pl. 1, Fig. 4). The cells of the uterine stroma and glands were not labelled either in the delayed implantation controls or in those treated with cyclic ApMP. No incorporation was seen either in the blastocysts or sections of uteri treated with RNAase.

The mechanisms involved in the early activation by oestrogen of the blastocyst lying free in the uterine lumen are not yet clear. The results reported in the present study show that cyclic ApMP mimics the early action of oestrogen in stimulating RNA synthesis in the delayed blastocyst and uterus. Cyclic ApMP has been shown to alter membrane permeability (Orloff \& Handler, 1962, 1967; Grantham \& Burg, 1966). Hechter, Yoshinaga, Halkerston \& Birchall (1967) showed that cyclic ApMP and other related nucleotides increase uterine RNA and overall protein synthesis in vitro, which is inhibited, but not abolished, by actinomycin $\mathrm{D}$; they suggested that these nucleotides may be participating in oestradiol action in the uterus by activating metabolic processes operative at the gene and other loci in the cell. It seems probable that the activation of the delayed blastocyst may involve among other processes some mechanism which alters cell permeability and thus allows increased availability of substrates for RNA synthesis.

This work was supported by grants from the Ministry of Health and Family Planning, Government of India, the Indian Council of Medical Research and the Ford Foundation.

\section{REFERENCES}

Cochrane, R. L. \& Meyer, R. K. (1957) Delayed nidation in the rat induced by progesterone. Proc. Soc. exp. Biol. Med. 96, 155.

Dass, C. M. S., Mohla, S. \& Prasad, M. R. N. (1969) Time sequence of action of estrogen on nucleic acid and protein synthesis in the uterus and blastocyst during delayed implantation in the rat. Endocrinology, 85, 528.

Grantham, J.J. \& Burg, M. B. (1966) Effect of vasopressin and cyclic AMP on permeability of isolated collecting tubules. Am. F. Physiol. 211, 255.

Griffin, D. M. \& Szego, C. M. (1968) Adenosine 3' $5^{\prime}$ monophosphate stimulation of uterine amino acid uptake in vitro. Life Sci. 7, 1017.

Hechter, O., Yoshinaga, K., Halkerston, I. D. K. \& Birchall, K. (1967) Estrogen-like anabolic effects of cyclic $3^{\prime}, 5^{\prime}$ adenosine monophosphate and other nucleotides in isolated rat uterus. Archs Biochem. Biophys. 122, 449.

MoHLA, S. (1968) Hormonal environment and blastocyst development in the albino rat. $\mathrm{Ph} . \mathrm{D}$. thesis, University of Delhi.

Mohla, S. \& Prasad, M. R. N. (1970) Early action of oestrogen on the incorporation of ${ }^{3} \mathrm{H}$ uridine in the blastocyst and uterus of rat during delayed implantation. F. Endocr. (in press).

OrLOFF, J. \& HANDLER, J. S. (1962) The similarity of effects of vasopressin, adenosine 3'5' phosphate (cyclic AMP) and theophylline on the toad bladder. F. clin. Invest. 41, 702.

OrLOFF, J. \& HANDLER J. S. (1967) The role of adenosine 3'5' phosphate in the action of antidiuretic hormone. Am. F. Med. 42, 757.

Prasad, M. R. N., Dass, C. M. S. \& Mohla, S. (1968) The action of oestrogen on the blastocyst and uterus in delayed implantation-an autoradiographic study. F. Reprod. Fert. 16, 97.

Szego, C. M. \& Davis, J. S. (1967) Adenosine 3'5' monophosphate in the rat uterus. Acute elevation by estrogen. Proc. natr. Acad. Sci. U.S.A. 58, 1711. 